Pokhodzilo M. Ivan Nechui-Levytskyi: Literaturnyi portret / M. Pokhodzilo. - K. : Dnipro, 1966. - S. 127.

Franko I. Anatol Patrykiiovych Svydnytskyi (uvahy do yoho "Liuboratskykh") / I. Franko // Zibr. tvoriv : u 50 t. / I. Franko. - K. : Naukova dumka, 1980. - T. 27. - S. 7-8.

Стаття надійшла до редакції 1 1.06.19.

Iryna Prylipko, Dr Hab, Associate Prof., Taras Shevchenko National University of Kyiv, Kyiv

\title{
REPRESENTATIVES OF CHURCH IN FICTION INTERPRETATION BY I. NECHUI-LEVYTSKYI
}

In the article exposes the peculiaritys of representation the clergy in I. NechuiLevytskyi's prose. Elucidates the specification of modeling the images, artistic means and style of texts. In the context of analysis of images system outlines the problematic and church-religious context of representation.

The artistic interpretation the clergy in I. Nechui-Levytskyi's prose conditions of personal experience by author, his observations and conclusions, bases on the realistic principle of representations. Realistic and satiric reception of clergy forming the variegated of representation the images of clergy, exposes their in the private, social, church-religious contexts. Important roles in the expose characters of clergy in I. Nechui-Levytskyi's prose plays the contrast's representation, portrait, connection typical and original features. The writer exposes positive and negative sides of activities of then clergy, accents on the depreciation of moral-ethical, spiritual factors in life and activities of clergy, exposes the causes of bad relations between clergy and people.

Keywords: clergy, image, theme, realism, satire.

УДК 821.161.2: 930.1. Нечуй-Левицький

Оксана Сліпушко, д-р філол. наук, проф., Анастасія Катюжинська, студ. Київський національний університет імені Тараса Шевченка, Київ

\section{ІСТОРИЧНІ РЕМІНІСЦЕНЦІЇ КОЗАЦЬКИХ ЛІТОПИСІВ У РОМАНІ І. НЕЧУЯ-ЛЕВИЦЬКОГО "ГЕТЬМАН ІВАН ВИГОВСЬКИЙ"}

Статтю присвячено дослідженню особливостей художньої інтерпретачії історичних подій $і$ постатей у романі "Гетьман Іван Виговський" I. НечуяЛевищького. Особливу увагу приділено інтерпретаиії специфіки барокової історіографії. Визначено характерні риси авторської історичної конщепції та вплив на ї̈ формування козацьких літописів. Проаналізовано художне переосмислення ролі й місия особистості в історії та історії в жстті людства 
у світогляді I. Нечуя-Левиџького. Обтрунтовано особливості трактування образу гетьмана Івана Виговського в козаџьких літописах і романі I. НечуяЛевииького в компаративному аспекті.

Ключові слова: художня інтерпретація, історія, історична постать, барокова історіографія, козацькі літописи, історичні ремінісиениії, I. Нечуй-Левицький, роман "Гетьман Іван Виговський".

Події національно-визвольної боротьби українського народу під проводом Б. Хмельницького й доби Руїни стали переломними в історії України й визначальними для формування подальшої суспільно-політичної ситуації і українського державотворення загалом. Отже, у сучасній історичній і літературознавчій науці немає однозначної оцінки щодо діяльності гетьмана Івана Виговського. Козацькі літописи як важливий чинник формування історичної концепції вперше репрезентують контекст історичної доби Руїни, зокрема постаті І. Виговського в ній. У творчості письменників другої половини XIXст. історичне буття народу стає предметом художнього аналізу, переосмислюється проблема особистості в історії та місця історії в житті людства. Власне, історична особа постає як державотворець, активний суб'єкт української історії.

Історична проза I. Нечуя-Левицького відзначається авторськими історіософськими та ідейно-естетичними поглядами, основується на особистому осмисленні й трактуванні української історії. Однак, на нашу думку, одним із джерел роману "Гетьман Іван Виговський" є козацькі барокові літописи.

Вивчення історичної прози I. Нечуя-Левицького представлене широким діапазоном виокремлених проблем, поданих у наукових розвідках Н. Бойко, Я. Вільної, А. Калинчук, О. Олійниченко, О. Поди, І. Приходько, М. Тарнавського, Б. Червака та ін. Дослідження специфіки репрезентації історичних подій у козацьких літописах належить Д. Багалію, П. Білоусу, М. Возняку, М. Грушевському, Я. Дзирі, Д. Дорошенку, М. Костомарову, Ю. Луценку, В. Соболь, І. Франку, Т. Чухлібу, В. Шевчуку, Н. Яковенко та ін. Питання своєрідності історичних ремінісценцій козацьких літописів у творчості письменників другої половини XIX ст., зокрема в історичній прозі I. НечуяЛевицького, ще не ставало предметом окремої наукової розвідки. Саме тому в сучасній літературознавчій науці актуальною 
залишається проблема художньої інтерпретації барокової історіографії у творчості письменників другої половини XIX ст., зокрема в історичній прозі І. Нечуя-Левицького.

Отже, метою роботи є проаналізувати історичні ремінісценції козацьких літописів епохи Бароко в романі "Гетьман Іван Виговський" I. Нечуя-Левицького, дослідити особливості інтерпретації історичних подій і постатей, обгрунтувати художнє переосмислення ролі й місця особистості в історії та історії в житті людства у світогляді І. Нечуя-Левицького.

Актуальність роботи зумовлюється необхідністю системного аналізу історичної прози I. Нечуя-Левицького, зокрема роману "Гетьман Іван Виговський", з огляду на історичні ремінісценції козацьких літописів у ній.

Новизна дослідження обгрунтовується тим, що вперше здійснено спробу аналізу роману "Гетьман Іван Виговський" I. Нечуя-Левицького 3 огляду на художню рецепцію козацьких літописів епохи Бароко в ньому.

Уперше період правління Івана Виговського зображено в козацьких літописах, зокрема в Літописі Самійла Величка подано як грунтовний опис діяльності гетьмана, так і аналіз його постаті. Літописець не просто викладає події в хронологічній послідовності, а репрезентує власні роздуми щодо історичних подій і осмислює роль І. Виговського в історії. На думку В. Шевчука, у козацьких літописах загалом репрезентовано проросійську орієнтацію, що спричинило негативну точку зору щодо I. Виговського: "Козацькі літописи, здебільшого, не були пам'ятками індивідуального суспільного думання, а пам'ятками думання певної верстви, у цім випадку кола діячів саме російської орієнтації... Очевидно, саме вони й спричинилися найбільшою мірою до творення негативного міфу про Івана Виговського..." [7, 299] Прихильною до зазначеної є думка Ю. Луценка, який вважає, що Григорій Граб'янка є "прихильником автономії України в союзі з Москвою... Він вибирає цей критерій - ставлення до Росії - як основний, і виходячи з нього, наділяє різних осіб тими чи іншими якостями" [2, 7]. Отже, на несприятливу оцінку I. Виговського вплинули пропольські орієнтації гетьмана i, як наслідок, неприйняття його ідей, 
негативне ставлення тогочасного суспільства до Гадяцького договору. Власне, І. Виговський, наслідуючи Б. Хмельницького, певною мірою відійшов від його політики, адже український народ, звільнившись від польського поневолення, не прагнув вступати в новий зв'язок з Польщею. У літописі Самійла Величка репрезентовано суспільні погляди самого автора, який був безпосереднім учасником тих подій. За переконанням В. Шевчука, літописець був виразником загальнокозацьких інтересів: "Він став на боці стану цілого козацтва, саме того, яке несло на своїх знаменах ідеї визволення та рівності, яке захищало демократичні вольності й права, ідеї, які робили цілий козацький рух прогресивним і світлим" [6, 198]. Саме тому, на думку дослідника, у літописі подано негативну оцінку гетьманів (за винятком Б. Хмельницького), зокрема І. Виговського, який не враховував інтереси всього козацтва. Окрім цього, Самійло Величко зазначає, що запорозькі козаки сприйняли вчинок гетьмана як зраду: "Ти не гетьман нам, а ми не є твоє військо, і не можемо приймати на себе нового зрадницького імені твого" [1, 243]. Відтак, лист козаків до I. Виговського Самійло Величко називає "листовною відозвою запорожців до Виговського з доганою йому за його зраду" [1, 242]. Як бачимо, загалом ставлення Самійла Величка до I. Виговського та його діяльності $є$ суто негативним. Літописець підтримує козаків, які засуджують дії гетьмана, зокрема те, що він відійшов від політики Б. Хмельницького й віддав Україну Польщі. Більше того, автор літопису викриває безкомпромісність і жорстокість I. Виговського в його боротьбі з М. Пушкарем. Власне, С. Величко виступає проти війни й міжусобиць загалом. Для літописця концептуальною основою міцної держави мають стати принципи єдності, миру й злагоди. С. Величко переконаний, що наступники Б. Хмельницького мають робити все, щоб не повторити події українсько-польської війни 1648-1654рр. Отже, літописець "засуджує I. Виговського і М. Пушкаря, бо їхні дії завдали шкоди загальному добру і в своїй основі мали гегемоністичний характер і не освітлювалися, як уважає письменник, постулатами загальної справедливості" [8, 478].

Системний аналіз роману "Гетьман Іван Виговський" дає підстави стверджувати, що I. Нечуй-Левицький подає власну 
історичну концепцію періоду правління I. Виговського. Не ідеалізуючи вчинки гетьмана, письменник дає кардинально протилежну оцінку його діяльності. Б. Червак стверджує, що I. Нечуй-Левицький "дає оцінку діям Виговського. Цьому присвячені цілі сторінки епілогу. Те, що Виговський не зрадник, однозначно" [5, 36]. На відміну від літописців I. НечуйЛевицький зосереджує увагу на психології вчинків гетьмана i характеризує його як "щирого патріота", "далекоглядного, тонкого політика", "оборонця прав України", "чоловіка великого розуму та європейської просвіти" [3, 338]. Водночас, політику гетьмана, зорієнтовану на Польщу, автор роману називає несвоєчасною i антинародною, адже український народ не готовий був знову пристати до Польщі. Тут, насамперед, йдеться про неприйняття i недостатню підтримку політики гетьмана серед народу, який розумів Гадяцький договір як загрозу нового польського наступу, що може призвести до поневолення українського народу й втрати ним державності: "Усе поспільство, усей народ, усі прості козаки загули, закричали проти цього гетьманського вчинку. Тільки десять років минуло, як народ визволився од польського ярма. Польське лихоліття було ненависне народові й простим козакам. Люди не встигли забутись про панщину, про всі неправди й пригноблення од панів та ксьондзів. Народ боявся, що знов вернуться на Україну вигнані Богданом католики-пани і силуватимуть його до панщини, боявся, що Польща знов заведе унію на Україні..." [3, 286] Окрім цього, народ не підтримав той суспільний лад, який планував запровадити I. Виговський: "Виговський заводив на Україні уклад старої Польщі або старої аристократичної Англії та феодальної Європи з привілейним панством. Його політика була регресивна, не національна, аристократична..." [3, 339] Як бачимо, ставлення українського народу загалом, і козацької шляхти зокрема, до Гадяцького договору в оцінці I. НечуяЛевицького цілком відповідає втіленій у козацьких літописах історичній концепції. Однак сам письменник прихильно ставиться до Гадяцького договору і вважає, що гетьман не зміг його реалізувати. За переконанням I. Нечуя-Левицького, Гадяцький договір був "найширшим актом автономії України за 
всю іï козацьку історію" [3, 338]. За умовами договору Україна мала отримати ши р. автономію, а I. Виговський ставав великим князем князівства Руського. Проте реакція українського народу, зокрема козацької спільноти, була негативною. Отже, козаки вважали, що гетьман цим вчинком запродав Україну Польщі, що призведе до повернення польських порядків і поневолення. 3 огляду на це, I. Нечуй-Левицький згадує у творі змову козаків вбити гетьмана: "Смерть гетьманові! Повісити б за це діло Виговського на першому дереві, на гілляці" [3, 290]. Разом із цим, письменник схвалює позицію І. Виговського, який не підтримує промосковської орієнтації і виступає проти союзу з Москвою. Письменник зазначає, що гетьман "не любив Москви за іiі непросвіченість і нещирість, бо постеріг своїм великим розумом, що Москва не додержить переяславської умови з Україною..." $[3,338] .3$ огляду на це, цілком правомірною вважаємо думку I. Приходько, яка вважає, що I. Виговський в оцінці I. НечуяЛевицького постає "патріотом України, що бажав вирвати іiі 3 лещат темної, деспотичної Москви, бажав їй просвіти, європейськості, аж ніяк не зрадником" [4, 33]. Як бачимо, письменник характеризує гетьмана як далекоглядного політика, який зміг оцінити й проаналізувати наслідки Переяславської угоди, а відтак, вбачав у Москві велику загрозу для українського народу: "Не пущу я тепер на Україну грубих причепливих московських бояр, одірву Україну од Москви і оддам в підданство польському королеві... Я поставлю умову для Польщі, щоб забезпечити міцніше незалежність од Польщі..." [3, 151] Гетьман зміг почути й усвідомити слова Б. Хмельницького, коли він дізнався про зраду Москви й відмову дотримуватися основних положень Переяславської угоди: "Москва не варта доброго слова. Нема й не буде нам підмогивід Москви...Треба оступитись од Москви. Коли Москва вчинила таке з нами, то треба оступитись од царя" [3, 107]. I. Виговський завжди чинив волю Б. Хмельницького, намагаючись наслідувати його політичну концепцію, тому ці слова стали основою ідейних переконань і поглядів гетьмана.

Однак гетьманство для I. Виговського було не лише можливістю поліпшити політичне становище України, зміцнити іiі суспільний лад і налагодити міжнародні зв'язки, а й тим, що 
принесе йому владу, славу й багатство. І. Нечуй-Левицький не ідеалізує постать гетьмана, а пише про його владолюбство й прагнення до розкоші. Сам I. Виговський після прийняття гетьманської булави зазначав: "Тепер я перевезу свою милу Олесю в цей палац з честю й славою, вдоволю іiї золоті давні мрії, обсиплю iї золотом і перлами. Народ не піде за мною, але в мене тепер сила в талярах..." [3, 151] Як бачимо, гетьман у романі I. НечуяЛевицького не усвідомлював повною мірою тієї загрози, що могла настати, якщо народ не підтримає його. Власне, I. Виговський не розумів, що сила гетьмана в його єдності 3 народом, у служінні на благо своєї країни, у боротьбі за іiі державність і незалежність. Крім цього, I. Нечуй-Левицький підтримує позицію козацьких літописців щодо жорстокості й підступності І. Виговського, засуджує братовбивство й міжусобну боротьбу гетьмана з М. Пушкарем. Письменник наголошує на тому, що війна призведе до страшних наслідків і руйнації держави.

Варто зазначити, що I. Нечуй-Левицький подає реакцію поляків на Гадяцький договір, яка, на думку письменника, була неоднозначною: "Варшава заспокоїлась і неначе повеселішала після важких воєн з козаками за гетьмана Богдана. Новий гетьман України Іван Виговський знов вертав Україну польському королеві" [3, 262]. Відтак, частина поляків, проаналізувавши Гадяцький договір, висловила згоду 3 його основними положеннями: "Не козаки порушували угоду, а ми... У всьому винна наша гордовитість. Ми з ними поводились не по людськи. Ми не тільки однімали од їх таки їх права, але позбавили їх усякого людського натурального права... Ми нижчі за їх: вони бились за волю, а ми - за безсиле панування..." [3, 270]. Як бачимо, автор роману акцентує увагу на тому, що ці пани ставилися до козаків як до людей і визнавали свої помилки, найважливішою 3 яких було порушення природного права українського народу на свободу. Водночас, були польські пани, які виступили проти умов Гадяцького договору, зокрема проти самостійності України й повного скасування унії, не погоджувалися 3 тим, щоб козаки отримали рівні з ними права: "Рівняти до себе хлопів, якихсь душогубів, лиходіїв, якихсь бунтарів, що встали бунтом проти своєї матері Польщі, якихсь пройдисвітів! Це буде ганьба, неслава для нашої шляхти!" [3, 269-270] 
Отже, на підставі аналізу роману "Гетьман Іван Виговський" I. Нечуя-Левицького доведено, що історична концепція письменника певною мірою пов'язана з положеннями барокової історіографії. 3'ясовано, що в основу козацьких літописів покладено історичні факти, основну увагу зосереджено на викладі подій у хронологічній послідовності. Натомість, у романі I. Нечуя-Левицького викладено художню авторську інтерпретацію історичних подій, зокрема періоду правління I. Виговського. 3'ясовано, що оцінка діяльності гетьмана відрізняється від викладеної в козацьких літописах. Відтак, на відміну від літописців, які негативно характеризують політичну діяльність I. Виговського, письменник репрезентує людську особистість як державотворця, активного суб'єкта в історії. Окрім цього, значна увага приділяється індивідуалізації образу правителя, зокрема розкриттю психології його вчинків. У художній інтерпретації І. Нечуя-Левицького гетьман І. Виговський виступає носієм політичних поглядів і світоглядних позицій, що відіграли вагому роль у становленні й розвитку ідеї української державності й стали продовженням історичної концепції та ідейних домінант козацьких літописів.

\section{СПИСОК ВИКОРИСТАНОЇ ЛІТЕРАТУРИ}

1. Величко С. Літопис / С. Величко ; пер. $з$ книж. укр. мови, вступ. ст., комент. В. Шевчука ; відп. ред. О. Мишанич. - К., 1991. - Т. 1. - 371 с.

2. Луценко Ю. Григорій Грабянка і його літопис / Ю. Луценко // Літопис гадяцького полковника Григорія Грабянки. - К., 1992. - С. 3-9.

3. Нечуй-Левицький І. Гетьман Іван Виговський / I. Нечуй-Левицький. - Л., 1899. -340 с.

4. Приходько I. Українська ідея у творчості I. Нечуя-Левицького / І. Приходько. - Л., 1998. - 70 с.

5. Червак Б. Образ гетьмана Виговського в українській літературі / Б. Червак. - Дрогобич, 1993. - 75 с.

6. Шевчук В. Дорога в тисячу років: роздуми, статті, есе / В. Шевчук. - К., 1990. $-411 \mathrm{c}$.

7. Шевчук В. Козацька держава як ідея в системі суспільно-політичного мислення XVI-XVIII ст. : у 2 кн. / В. Шевчук. - К., 2007. - Кн. 1. - 717 с.

8. Шевчук В. Муза Роксоланська: українська література XVI-XVIII століть : у 2 кн. / В. Шевчук. - К., 2005. - Кн. $2-728$ с. 


\section{REFERENCES}

1. Velychko S. Litopys / S. Velychko ; per. z knyzhnoi ukrainskoi movy, vst. stattia, koment. V. Shevchuka; vidp. red. O. Myshanych.-Kyiv : Dnipro, 1991. - T. 1. - 371 s.

2. Lutsenko Yu. Hryhorii Hrabianka i yoho litopys / Yu. Lutsenko // Litopys hadiatskoho polkovnyka Hryhoriia Hrabianky. - Kyiv: Tovarystvo "Znannia" Ukrainy, 1992. - S. 3-9

3. Nechui-Levytskyi I. Hetman Ivan Vyhovskyi / I. Nechui-Levytskyi. - Lviv : Dilo, 1899. - $340 \mathrm{~s}$.

4. Prykhodko I. Ukrainska ideia utvorchostiI. Nechuia-Levytskoho / I. Prykhodko. - Lviv : Kameniar, 1998. - 70 s.

5. Chervak B. Obraz hetmana Vyhovskoho v ukrainskii literature / B. Chervak. Drohobych : Vidrodzhennia, 1993. - 75 s.

6. ShevchukV. Dorohavtysiachurokiv: rozdumy, statti, ese / V. Shevchuk. - Kyiv : Radianskyipysmennyk, 1990. - 411 s.

7. Shevchuk V. Kozatska derzhava yak ideia v systemi suspilno-politychnoho myslennia XVI-XVIII st. : u 2 kn. / V. Shevchuk. - Kyiv : Hramota, 2007. - Kn. 1. - 717 s.

8. Shevchuk V. Muza Roksolanska: Ukrainska literatura XVI-XVIII stolit : u 2 kn. / V. Shevchuk. - Kyiv : Lybid, 2005. - Kn. 2. - 728 s.

Стаття надійшла до редакції 14.10.19.

Oksana Slipushko, Dr Hab., Prof., Anastasiya Katyuzhynska, student, Taras Shevchenko National University of Kyiv, Kyiv

\section{HISTORICAL REMINISCENCES \\ OF THE COSSACK CHRONICLES IN THE NOVEL "HETMAN IVAN VYHOVSKY" BY I. NECHUY-LEVYTSKY}

The article is devoted to the study of the peculiarities of the artistic interpretation of historical events and figures in the novel "Hetman Ivan Vyhovsky" by I. NechuyLevytsky. Particular attention is paid to the implementation of the specifics of Baroque historiography in the novel. The characteristic features of the author's historical conception and influence of the cossack chronicles on its formation are determined. The historical fiction of I. Nechuy-Levytsky is represented by author's historiosophical and ideological-aesthetic views, based on personal understanding of the Ukrainian history. I. Nechuy-Levytsky presents his own historical conception of the period of I. Vyhovsky's activity, which is connected with certain features and characteristics of the provisions of Baroque historiography. An artistic rethinking of the role and place of personality in history and history in the life of humanity in the worldview of I. Nechuy-Levytsky is analyzed. The peculiarities of the interpretation of hetman Ivan Vyhovsky's character in the cossack chronicles and the novel by I. Nechuy-Levytsky in the comparative aspect are substantiated. It is determined, that the estimation of hetman's activity differs from that set out in the cossack chronicles. Therefore, unlike the chroniclers, who negatively characterize the political activity of I. Vyhovsky, the writer represents the human personality as a state creator, active subject in history. 
In addition, much attention is paid to the individualization of the image of the ruler, in particular the disclosure of the psychology of his actions.

In conclusion, in the artistic interpretation of I. Nechuy-Levytsky hetman I. Vyhovsky is represented as the bearer of political views and ideological positions, that played a significant role in the formation and development of the idea of Ukrainian statehood and became a continuation of the historical conception and ideological dominants of the cossack chronicles.

Keywords: artistic interpretation, history, historical figure, baroque historiography, cossack chronicles, historical reminiscences, I. Nechuy-Levytsky, the novel "Hetman Ivan Vyhovsky".

\section{УДК: 821.161.2I. Нечуй-Левицький}

Анатолій Ткаченко, д-р філол. наук, проф., Київський національний університет імені Тараса Шевченка, Київ

\section{ЕТОЛОГІЧНА ОПОВІДЬ КЛАСИКА}

Звернуто увагу на потребу нового текстологічно вивіреного безцензурного видання творів I. Нечуя-Левищького, куди слід долучити й раніше не публіковані та маловідомі тексти. Зокрема, йдеться про нарисову оповідь "Як сахарні голови літали в повітрі", написану понад сто років тому та з невідомих причин не віддану до друку.

Ключові слова: оповідання, нарис, нарисова оповідь, етологія, міжетнічні взаємини, реалістичний стиль.

1914 р. він був уже класиком української літератури. Готував цей твір, як зазначено на титульному аркуші рукопису, "для будущого журналу "Основа" або для XII т. повістів і оповіданнів". Завадили, мабуть, початок Першої світової війни, наступні революційні події та підупале здоров'я (за чотири роки по тому письменник помер).

Через понад піввіку Віра Аполінарівна Левицька, внучата племінниця Івана Семеновича, уперше й востаннє опублікувала текст твору в журналі "Радянське літературознавство" (1978, № 12), на жаль, у трохи препарованому вигляді. Як зазначено в преамбулі, автограф зберігається у відділі рукописів Центральної наукової бібліотеки АН УРСР (ф. І, од. зб. 27833) (нині це Національна бібліотека України імені В. І. Вернадського). Рукопис чорновий, "про що свідчать певна мовностилістична невідшліфованість тексту, численні закреслення та виправлення тощо" $[1,66]$. 